\title{
Some Australian official views of New Caledonia's Melanesians, 1941 to 1953
}

Des vues officielles australiennes des Mélanésiens de Nouvelle-Calédonie

(1941-1953)

\section{Stephen Henningham}

\section{CpenEdition}

\section{Journals}

Electronic version

URL: http://journals.openedition.org/jso/7367

DOI: $10.4000 /$ jso.7367

ISSN: $1760-7256$

Publisher

Société des océanistes

Printed version

Date of publication: 15 December 2015

Number of pages: $323-336$

ISBN: 978-2-85430-126-7

ISSN: 0300-953x

\section{Electronic reference}

Stephen Henningham, « Some Australian official views of New Caledonia's Melanesians, 1941 to 1953 », Journal de la Société des Océanistes [Online], 141 | juillet-décembre 2015, Online since 15 December 2018, connection on 02 May 2019. URL : http://journals.openedition.org/jso/7367 ; DOI : 10.4000/ jso.7367 


\section{Some Australian official views of New Caledonia's Melanesians (1941 to 1953)}

by

Stephen HENNINGHAM*

\begin{abstract}
In the decade or so from 1941, Australian military officers and government officials paid some attention, for the first time, to the Melanesians of New Caledonia. Their comments illuminate Australian attitudes in that period, and offer perspectives on a significant stage in the history of New Caledonia, in terms particularly of the partial enfranchisement of the Melanesians.
\end{abstract}

KeYwords: Melanesians, Second World War, Suffrage, Australia, New Caledonia

" [The Melanesian troops] are of excellent physique, can move quickly in close country and are adaptable[...] " (Australian Mission, 1941)

"The natives are a fine race, intelligent and strong. " (Kneen, quoted in Lawrey, 1982)

« [...] having a history of savagery, they have been regarded by Europeans as of little economic significance. They are used for heavy unskilled work, but are reported to be lazy. On the other hand, they make good stockmen on cattle stations [...] The ability of at least some to proceed to higher education is demonstrated by the recent ordination of two of their number to the Catholic priesthood [...]» (Smith, 1948).

" [There was a] [...] widespread tendency in the European community to regard Lenormand as representing native as opposed to European interests, a tendency associated with strong racial prejudice however unexpected among Frenchmen, against his wife. » (Anderson, 1951b)

These four quotations highlight aspects of the views of Australian military officers and civilian

\section{RÉSUMÉ}

Dans les années 1941-1953, les officiers militaires et les fonctionnaires australiens ont porté pour la toute première fois une certaine attention aux Mélanésiens de NouvelleCalédonie. Leurs commentaires éclairent les perspectives australiennes de cette époque et documentent une phase importante de l'histoire de la N $N^{\text {Ille-Calédonie, notamment }}$ l'accession d'une partie des Mélanésiens au droit de vote.

Mots-CLÉs : Mélanésiens, Deuxième Guerre mondiale, élections, Australie, Nouvelle-Calédonie

officials on the Melanesians of New Caledonia and Dependencies (hereafter New Caledonia) in the decade or so from 1941. After providing background on Australian preconceptions and on Australian interest in New Caledonia during the period under review, this article discusses some of the views on the Melanesians provided during the war, mainly by military officers. It then considers, in more detail, the views of Australian officials in the years following the war. Only a small number of Australians, we should note, served in New Caledonia as military officers or officials in the period under review: probably no more than twenty overall, with some of them spending only a few months there. The article presents direct quotations in an effort to 'bring to life' the views expressed, and to share source material which is not well known in Australia or elsewhere. There was a tendency for these Australian observers to rely on second-hand information, which diminished

* Canberra, stephen.henningham@gmail.com 
the quality of the information they collected and conveyed. Their reports sometimes over-simplified or distorted some aspects, presumably because of imperfect understanding and/or because of an effort to present information in terms more readily comprehensible to the intended audience. Now and again I have added comments to provide background or to help correct the historical record. But I have not done this on all occasions, given that my main concern is to present some of the views of Australian observers during a particular historical period. The discussion of these various views often covers familiar ground, corroborating understandings established in a number of scholarly studies, notably in Ismet Kurtovitch's comprehensive account (1998). But I hope that the discussion also offers additional insights and information, and casts an interesting sidelight on the Melanesians of New Caledonia, and on Australian views on them, in an era when they began to emerge slowly into the mainstream of the life and politics of New Caledonia.

\section{Preconceptions}

What were the likely preconceptions of these Australian observers when they arrived in New Caledonia? In the 1940s and early 1950s the great majority of Australians were descendants of immigrants from the British Isles, or else were recent British or other European migrants. They mostly saw non-European peoples through a lens of racial stereotypes and prejudice, and regarded some 'races' as less advanced than others. The specific views of these observers on New Caledonia and its Melanesian population were probably also shaped by press items and by contemporary and earlier books and articles. Some of these texts were of a genre epitomized by the title of H.E. Lewis Priday's Cannibal Island: The Turbulent Story of New Caledonia's Cannibal Coasts (Priday, 1944). One likely influence was Wilfred Burchett's Pacific Treasure Island. Published in Sydney in early 1941, this lively survey sold well.

The scattered references to New Caledonia's Melanesians in the 1940s and early 1950s in the National Archives of Australia indicate that contacts with Melanesians by Australian representatives were infrequent and transitory. John Lawrey, a career diplomat who was a junior official in New Caledonia in 1941 and 1942, and who was ActingAustralian Consul in Noumea for several months in 1950, recalled that the Melanesians

«[...] form[ed] a background to wartime events but, in the atmosphere of that time, not much more. » (Lawrey, 1982 : 9)

Nonetheless, the views expressed by military officers during the early war years were based in part on direct contact with the Melanesians themselves. In contrast, the views expressed by Australian officials later in the war and in the postwar years generally do not reflect direct contact.

The military officers travelled widely in New Caledonia and some were based in remote areas. In contrast, the civilian officials lived in Noumea, the capital and main town, and made only occasional visits to the interior. In the 1940s and 1950s (and for many years afterwards) Noumea was a very 'white' town, with Melanesians present only on its margins. The European French, who dominated Noumea and New Caledonia, consisted of two groups: the 'metropolitan' French and the Caledonians. The metropolitans numbered a few hundred and worked in official, professional, business, and technical positions. They mostly stayed in New Caledonia for only a few years. The Caledonians were a settler community derived from immigration from France since the latter half of the nineteenth century. The work and social contacts of an Australian official were very rarely with Melanesians, as several documents show (Commonwealth of Australia, 1948; External Affairs, Pacific Division, 1948; External Affairs, 1949). Their contacts were with French metropolitan officials, occasionally with French businessmen and clergy, and with the Caledonians. Australian officials had good relations with members of the Caledonian elite. For example successive Australian consuls were on cordial terms with Senator Henri Lafleur, from whom, until mid-1954, the Australian government leased the Consulate's combined office building and residence (Cumpston, 1954). The views of Australian officials on the Melanesians were often second hand, derived in part from engagement socially in a masculine world of after-work drinks and camaraderie. According to one account:

"Two or three miles from the heart of Noumea is the "Biarritz" nightclub standing on the beach at Anse Vata. Many of the notabilities drive to the Biarritz between 5.30 p.m. and 7.30 p.m. Here one offers hospitality, the Biarritz making a substantial profit out of one's generosity - a small bottle of French beer costing, for example, 5/- [5 shillings]. » (Commonwealth of Australia, 1948: 3).

\section{Australia and New Caledonia in the 1940s and early 1950s}

In the 1920s and 1930s Australian knowledge and awareness of New Caledonia was sketchy (Lawrey, 1982: 16-19). But with the Fall of France in 1940, combined with fear of Japan, New Caledonia became important to its large neighbour. Australia intervened in September 1940 to help win over New Caledonia to Free France, and for the rest of the war provided self- 
interested but appreciated defence and economic assistance (Lawrey, 1982). Under the Australian Labor governments from 1941 to 1949, External Affairs Minister Herbert Vere Evatt championed Australian engagement in the South Pacific (Thompson, 1998: 116-17). On 14 October 1943 Evatt told Australia's parliament that it was

«[...] essential that [...] there should be a very close and intimate relationship between Australia and New Caledonia. »

Australian interest continued after a conservative government came to power in December 1949. In May 1950 External Affairs Minister Percy Spender set out the importance to Australia of nearby island groups, including New Caledonia.

«[...] Australia has a duty to itself which must not be neglected. This is the duty of ensuring by every means open to us that in the island areas immediately adjacent to Australia, in whatever direction they lie, nothing takes place that can in any way offer a threat to Australian security, either in the short or the long term. These islands are, as experience has shown, our last ring of defence against aggression, and Australia must be vitally concerned with whatever changes take place in them[...] New Guinea happens to be largest and most important of those island areas that are of direct concern to us. But in the same way we cannot be passive observers of any developments in Timor, the New Hebrides and New Caledonia that might have unwelcome consequences for Australia. " (Spender, 1950)

In 1950 Spender raised with France the Australian use of air and naval facilities in New Caledonia, but did not pursue this idea (Mohamed-Gaillard, 2010: 38; Aldrich, 1993: 59-60). In the late 1940s and early 1950s Australia campaigned successfully against the use of Japanese contract labour in New Caledonia (Henningham, 2016). Overall, in the decade or so from 1941, New Caledonia received more Australian official attention than in the preceding decades, and more than it would again receive until the emergence of militant Kanak nationalism in the late 1970s. Some of that attention involved consideration of the Melanesian population, at first in terms of its contribution to the war effort, and then later with respect to the implications of its participation in electoral politics.

Who were they, these Melanesians, in the period reviewed here? In 1945 the population of New Caledonia comprised 31,000 Melanesians, 18,000 Europeans, and 13,500 'Others', most of whom were Indonesian and Vietnamese indentured workers (Brou, 1981: 1; Leblic, 1993: 30-31). The indentured workers usually returned to their home countries after completing their contracts, although this was not possible during the war years. Until after the war the Melanesians were French subjects rather than French citizens, and their movements and activities were strictly regulated under a 'Native Code'. They exemplified the diversity characteristic of Melanesia. There were nearly thirty indigenous languages; French was their lingua franca. Members of each indigenous language group formed one or more tribal groups, in turn divided into clans, the key unit for identity and social organisation. Chiefly systems prevailed, but their nature varied. There were important differences between the main island of New Caledonia (La Grande Terre) and the Loyalty Islands. Colonialism had brought many changes, including, on the main island, forced movement of populations onto reserves following defeat in colonial conflict or to make way for the transfer of land to settlers. Conversion to Christianity had created a further distinction between Catholics and Protestants, often related to clan and tribal rivalries (Connell, 1987: 9-15, 27-31; Guiart in Deschamps and Guiart, 1957: 114-120; Leblic, 1993: 79-82; Leblic, 2007: 273-274).

In the French language of this era, the Melanesians were often still known as Canaques, an often derogatory term, or as Indigènes (natives), a more neutral term. In the late 1940s the French administration often used the neutral word 'Autochtones', which meant 'original inhabitants'. In the 1950s the term 'Mélanésiens' (Melanesians), previously mainly used in scholarly work, came into common usage, generally replacing the terms used earlier. Because of the diversity and limited cohesion of the Melanesian population during this period, 'Melanesian' is used this article as a broad descriptive term, rather than as a designation of a community with a matured sense of identity.

\section{The war years}

In February 1941 the Australian Government sent a military mission to assess and advise on New Caledonia's defence, given concerns about a possible Japanese thrust south. The mission was impressed by the Melanesian troops, who served under metropolitan and Caledonian officers and non-commissioned officers, describing them as «[...] powerfully built and active." They were reportedly 'soft' because of their diet but hardened up quickly once on military rations. They were also

«[...] said to be stronger than the Tahitians, but not so intelligent. They are undoubtedly very keen. » (Australian Mission, 1941: Appendix 10)

\section{They were,}

" [...] of excellent physique, can move quickly in close country and are adaptable [...]. The work done in the one tactical exercise witnessed was very creditable. They know the terrain inside out. » (Australian Mission, 1941: 31) 


\section{The mission commented that the}

"Natives [are] said to be mostly for de Gaulle, but actually they probably understand or care little about politics. » (Australian Mission, 1941: 42)

Next, in mid-1941, Captain T.P. Kneen conducted a secret mission to investigate political and military conditions. He concluded that the terrain of the main island was ideal for guerrilla operations. He reported favourably on the Melanesians, noting their readiness to volunteer:

"The natives are a fine race, intelligent and strong. They are loyal subjects, of whom more wish to enlist than can be accepted [...] In some districts, however, notably in the far North, they have always at the back of their minds the fact that the French came and took their land only 80 years ago." (Quoted in Lawrey, 1982: 124)

As Kurtovitch (1996: 6) notes, it appears that the enlistment rate of the Melanesians was higher than that of the Caledonians.

For the first few months after the start of the Pacific war in December 1941 the Australian government feared that a Japanese attack on New Caledonia was imminent. From December 1941 to July 1942 an Australian commando company served there. It prepared for a possible guerrilla campaign against a Japanese force, including by training 'native scout' detachments. It also trained elements of the large American force that arrived in March 1942. The commandos' unit history described the Melanesians as 'friendly and cooperative' (Garland, 1997: 12). One of its officers reported that:

"Our men came to be held in high regard both by the New Caledonian French and by the natives, which latter gave us the greatest assistance wherever we went. This gave the lie to earlier reports that the natives of New Caledonia were treacherous and cunning. " (Dennis, quoted in Lawrey, 1982: 124).

In early January 1942, the Minister of External Affairs offered the assessment, based on what his military and other advisers had told him, that if properly supplied:

" [The] New Caledonians will fight and fight well [...]. Their record as soldiers was good in [the] last war, and natives from the Loyalty Islands made excellent sailors. » (External Affairs, Minister, 1942)

The reference here to 'New Caledonians' presumably covered both Caledonians and Melanesians, but this is not certain.

We should also note a comment on Melanesian capacity in a book by Australian journalist Wilfred Burchett. Dorothy Shineberg (1986) points out that Burchett's main engagement was with Caledonians. For him, as fellow « [...] younger sons of empire ", the Caledonians had an affinity with white Australians (Burchett,
1941: 222). But in his 1941 book he also celebrated the skills and capacity of 'Emile', a Loyalty Islander. He commented:

« For those people who believe that Kanakas are stupid, incapable and unwilling to learn, I should like to present Emile as the living proof of their error. " (Burchett, 1941: 46)

Burchett's book was the only up-to-date English-language account of New Caledonia. It was used in Australian military circles: when Ron Couche and his fellow commando officers were being briefed while en route to New Caledonia, they were each given a copy. Couche recalled that:

«It was to prove a very useful book [...] » (Garland, 1997: 18)

In the later phase of the war, from mid-1942, the Australian officials and military officers in New Caledonia were mainly in contact with French officials and Caledonian leaders, and with officers of the American forces stationed there. They had little direct contact with Melanesians. However the Australian government showed interest from time to time. In July 1943 the Department of External Affairs (DEA) asked the Australian representative in New Caledonia, B.C. (Bertram) Ballard to report on indications that the United States might seek to maintain a presence in New Caledonia and the New Hebrides after the war (External Affairs, July 1943). Before arriving in New Caledonia in August 1940, Ballard has been Australia's legal representative in the New Hebrides. Among other topics, Ballard was asked to report on

" the effects of wartime developments on native life [...] [and] [...] any other wartime activities which may affect future $[\ldots]$ native policy. "

\section{Ballard responded that}

"The principal effect of present circumstances on the native population has been to confer considerable wealth on them in return for their services as laundrymen and camp followers generally; this has resulted in a certain reluctance to engage in agricultural work for the coffee-growers and other agriculturalists to the former extent, but the Administration has brought pressure on them to do so. »

Meanwhile, in the neighbouring New Hebrides,

"The open handedness of the Americans will by now be perfectly known throughout the Group, and the natives will be quite happy to see the Americans stay indefinitely, for this reason, but there is not the slightest evidence of their being dissatisfied with the present governmental arrangements, and in the main native communal and village life has not been disrupted. » (Ballard, 1943) 
In December 1943 DEA again sought Ballard's advice on various subjects, including 'native education and health', as part of preparations for an Australian/New Zealand meeting in January 1944 (External Affairs, December 1943). Among other things, the meeting would consider native welfare and advancement. Ballard reported as follows.

"As education, both state and mission, is carried out in French, most of the natives, and certainly all the younger ones, now understand and speak the language well enough for all common purposes. Of the 5,430 able-bodied native men, 1,186 have enlisted in the Army and Navy, 1,000 are employed privately, 500 are employed by government departments, and upwards of 1,150 by the U.S. Army (i.e. a total of more than 3,836); the remainder living in the villages is considered to be an indispensable minimum[...] Since the arrival of service personnel in great numbers, the native ideas of material well-being have risen considerably - not only lavish gifts of food and clothing, but also high wages paid for small services are responsible for this. In the country districts, however, apart from the absence of the men mentioned above, the main structure of village life has remained unaltered. » (Ballard, 1944)

Ballard's comments are in neutral terms, but tie in with scholarly accounts of the very heavy demands made on the Melanesian population during the war (see Kurtovitch, 1992, 1996 and 1998). Ballard also noted that in the hospital in Noumea,

"The native and isolation wards are overcrowded, and their hygienic condition has been stated by the Director of the Service to be "deplorable", resulting in such occurrences as the infection of patients in other sections of the hospital with amoebic dysentery during their treatment. Moreover, in the isolation ward European, native and Asiatic patients are all treated together, nor can those suffering from different diseases be kept separate. » (Ballard, 1944)

\section{The immediate post-war period, 1945 to 1949}

In 1946 the French government instituted important reforms in France's overseas possessions, including granting French citizenship to indigenous peoples. In New Caledonia the abolition of the Code de l'Indigénat (Native Code) removed residential, work and other restrictions (see Kurtovitch, 1997a; Leblic, 1993: 53-54). The granting of citizenship appeared to open the way for the Melanesians to gain the right to vote. The reforms implemented in New Caledonia in the post-war years, we should note, would put the Melanesians in a much better position, in terms of political rights, than the indigenous populations of Australia itself and of its overseas territories during that period.
In May 1946 the Australian representative in New Caledonia, Hal Barnett, a former lieutenantcommander who had been a naval liaison officer in Noumea for some months in 1942, reported on the outcome of voting on a proposed new French constitution. In metropolitan France the constitution had been only narrowly rejected, but in New Caledonia three-quarters of those who voted had voted against it. (A more moderate constitution subsequently won overall support and was enacted.) Barnett underlined the significance of what he understood as a proposal in the rejected constitution to give the vote to

\section{" [...] all native peoples in the French colonies. »}

He believed this proposal had strongly influenced the voting in New Caledonia, because the Melanesians outnumbered:

«the French population by about two to one. By no stretch of the imagination can one visualise the New Caledonian French endorsing a constitution which would give the Kanakes $[s i c]$ a voting power of two to one vis à vis themselves. New Caledonia and Dependencies are represented in the Chamber of Deputies by a single member, and New Caledonians, not unnaturally, considered as inevitable the ultimate election of a Kanaka deputy to represent New Caledonia had the Constitution been accepted. " (Barnett, 1946)

Barnett said there might have been a political crisis if the referendum had decided in favour of the proposed constitution. He declared that:

"So strong is the opposition to the enfranchisement of the Kanakas that some people say they would seek autonomy rather than submit to a constitution which incorporated this principle. "

Before the election there had even been discussion

" [...] of the relative advantages of a rapprochement with Australia or the United States in the event of a bid for autonomy.' He noted that, 'Generally in politics New Caledonians talk much and do little.»

(Here Barnett is referring to the Caledonians when he uses the term 'New Caledonians', rather than to the total population of the territory.) But, he noted, the Caledonians had taken part in direct action during the war, first in support of the rallying of New Caledonia to Free France in September 1940 and then later, in May 1942, in protest against the conduct of Admiral d'Argenlieu. He advised that:

«[...] should enfranchisement of the local natives ever become an accomplished fact there is the remote possibility of an autonomous movement developing $[\ldots]$ " 
As this could involve an approach to Australia, he suggested that thought should be given

\section{«[... $]$ to this potential problem in advance.»}

Barnett's use of various inconsistent and derogatory terms in his comments (Kanakes, Kanakas, Kanaka) indicates not only a lack of knowledge but also a lack of comfort with the extension of voting and other rights to the Melanesians.

The following January, Barnett noted that recent voting patterns in New Caledonia had reflected strong anti-communist feeling. He believed the main reason for Caledonian opposition to communism was because the French Communist Party envisaged

«[...] the enfranchisement of all French native peoples. As the Canaques or "Indigènes" in the Island outnumber the white population by two to one, New Caledonians simply regard the proposal to grant universal suffrage to the Canaques as tantamount to handing over to them the control of New Caledonia. The significance of events in the Netherland East Indies is not lost on them and they fear that it would only be a matter of time before the Canaques developed the aggressive nationalism of the Indonesians were the former granted the privilege of universal suffrage. It is hardly likely that such would be the immediate effect of enfranchisement but that is how New Caledonians regard the proposal and it can be taken for granted that they will oppose this step to the last ditch. " (Barnett, 1947)

In these remarks, Barnett refers again to the Caledoniansas 'New Caledonians', acknowledging their primacy, and discounting the presence of the Melanesians. But his conceptualization of New Caledonia's Melanesians has evolved at least insofar as he now refers to them as 'Canaques' rather than 'Kanakas'. His reference to the 'aggressive nationalism' of the Indonesians appears to relate to the (ultimately successful) challenge to Dutch rule in the 'Dutch East Indies' of the Indonesian nationalist movement, rather than specifically to electoral and voting issues ${ }^{1}$.

In the event the Caledonians did not oppose the extension of the franchise to the last ditch, but they did mount a successful delaying action. Under an ordinance of August 1945 the French government had granted New Caledonia a deputy in the French parliament. The suffrage was extended to the following categories of Melanesian men: returned servicemen, chiefs, pastors, assistant-teachers and nurses. The number totalled 1,144, some 11 per cent of the Melanesian adult population. In October 1946 the vote was extended to additional categories of adult Melanesian males, without, however, substantially increasing the number of Melanesian voters. Meanwhile the extension of the vote to European French women had more than doubled the number of European French (Caledonian and metropolitan) electors, bringing their number to over 9,000 (Brou, 1981: 9, 12). Article 4 of the Constitution of the Fourth Republic, enacted in 1946, gave all citizens over 21 the right to vote. But another article (number 80 ) prescribed that in the overseas territories specific laws would set out eligibility. Angleviel (2006: 24) comments that the delay in the substantial extension of the franchise to the Melanesians meant that for some years New Caledonia was the only French Overseas Territory lacking any indigenous representative in its Conseil général (General Council), the local self-governing body.

In early 1948 New Caledonia's Melanesians again attracted some official Australian attention, when the Australian Government sent an 'Economic Mission' to New Caledonia, tasked with looking into ways into which the AustralianNew Caledonian economic relationship could be consolidated and strengthened (see Henningham, 2014). In his lengthy report, J.T. (John) Smith, a keen young official from the Department of Trade and Commerce, made some references to the Melanesians, including these remarks.

\begin{abstract}
"The Natives were an important factor in the settlement of the Colony. Hostile from the start to white occupation they proved a menace to all attempts to expand the early settlement. [...] they were cannibals and in 1878 organised a great revolt which might have succeeded in wiping out the European population. Even as late as 1917 a native revolt had to be quelled but today they are reported to be peaceful and harmless. " (Smith, 1948: 13).
\end{abstract}

Smith described them as being of '[...] Melanesian origin' but added that the '[...] natives in the Loyalty Islands show a strong admixture of Polynesian blood.' In a later passage he commented that:

«In general, Melanesians have proved difficult of adaption to Western methods of labour. Primarily small-scale agriculturalists or fishermen and having a history of savagery, they have been regarded by Europeans as of little economic significance. They are used for heavy unskilled work, but are reported to be lazy. On the other hand, they make good stockmen on cattle stations and doubtless the spread of education among them will, in time, do much to improve them as workers. The ability of at least some to proceed to higher education is demonstrated by the recent ordination of two of their number to the Catholic priesthood, for which a further 28 are studying at the local seminary in Paita. » (Smith, 1948: 59-60).

Smith's view of the New Caledonian Melanesians generally seems to have been that of many Caledonians of that era, namely that essentially the Melanesians had been and were an obstacle to the successful development ${ }^{2}$ of a settler colony. However he did also note that 'no real attempt' had been made

1. On communist influence in New Caledonia at this time, see Kurtovitch, 2000.

2. On the Melanesians and developement issues, see Leblic (1993). 
« [...] to develop the native population so as to enable it, in time, to become an integral part of the community. " (1948: 86-87)

Later in 1948, K.T. Kelly, acting as Consul while Barnett was on leave, reported that

«[...] the 30,000 Melanesians on the Island make little or no direct contribution to production of goods for export. "

In his view the Melanesians could not take the place of the Indonesian and Vietnamese workforce (Kelly, 1948). The background here is that after the war there was a labour shortage. This shortage resulted in part from the gradual repatriation of many of the Asian workers, whose return home had been prevented by the war. Most of the Asians who remained were unwilling to continue in their previous employment. On 15 June 1945, the French government had released the Asian workers from their contracts. The New Caledonian administration attempted unsuccessfully to constrain their places of residence, in order to keep them engaged in mining and agriculture in the interior. Most of them moved to Noumea, where they worked as labourers and artisans, or set up small enterprises. In Kelly's assessment, the Melanesians would suffer if they became proletarian miners. 'In the short-term view', he noted, 'Melanesian labourers cannot meet the needs of the exporting section of the Island's economy.' Kelly concluded that:

"An increase in the population (and naturally in the labour supply) of the Island is essential if the Colony is to establish for all its present inhabitants a reasonably high European standard of living. Such a standard, even for the Melanesians, appears to be the goal of the French administration. » (Kelly, 1948)

His remark that progress was apparently intended 'even for the Melanesians' displays an attitude characteristic of many Australians at that time.

\section{The early 1950s}

In the early 1950s Australian diplomatic reporting on the Melanesians continued to be episodic, but offered some insights. On 30 June 1950 the high chief of Mare (one of the Loyalty Islands), Henri Naisseline, contributed to Le Calédonien, a left wing newssheet. In his article he complained about the modest payments given to the chiefs. They were paid 800 to 1,200 francs a month whereas an office boy got 2,250 francs a month. He noted that some minor and high chiefs

«[...] are proud to be called by their official titles and to wear a fine uniform with gold rank badges. Poor high chiefs! Our rank badges are of no use but to obtain cheap or even free labour when the Administration asks for it. » (Quoted in Lawrey, 1950)

Moreover, the chiefs were not given a travel allowance, and relied on the hospitality of their 'subjects' when travelling. As a result, Naisseline said,

" [...] the latter - most of them heads of families - have to kill their poultry and livestock to feed their chiefs. "

In his comments on the article, Acting-Consul Lawrey described Naisseline as able and well educated, and

« [...] the outstanding figure among the Territory's native notables. »

Referring to the General Council, which at that time was dominated by conservative Caledonians, Lawrey said Naisseline's remarks in the press article indicated that

" [...] some at least of the native notables have not been convinced by the General Council that all is for the best in the best of all possible colonial worlds. »

Lawrey commented on France's rule of the tribal villages in New Caledonia through a hierarchy of chiefs

" [...] whose authority was very largely created by the French as an instrument of government to replace the chaotic clan system $[. .$.$] "$

Some years earlier, (presumably during his service as assistant to Ballard during the war), the then Secretary General of New Caledonia had told him that 'We give them a semblance of authority.' Indeed, Lawrey observed,

«[...] the chief in his gold-braided uniform is often not much more than a façade designed to obscure the less picturesque figure of the corporal of gendarmerie who really represents authority [...] "

Lawrey also recalled that General de Gaulle sent Naisseline a letter thanking him

« [...] in warm terms for the contribution made by the numerous Maré natives who enlisted in the Free French naval forces [during the war].' "

Some Caledonians, he said, had expressed concern that the General

« [...] might give the chiefs ideas above their station if he took actions of this kind.»

In these years Melanesians were slowly beginning to engage more fully with the wider economy and society. In April 1951 a new Australian Consul, H.D. (David) Anderson, a young career diplomat with previous postings in France and Pakistan, and who had served in the Australian army in Papua New Guinea during 
the war, reported on a visit to the Tiébaghi chrome workings. Anderson described this operation as New Caledonia's main producer of chrome, and said that over 70 Melanesians were working underground there. According to the manager, Mr Bergman, an American, the Melanesians were

« [...] at least as hard-working and efficient as their co-workers of other races. »

This was because they were getting the same wages and same treatment as their fellow workers. The Melanesian workers were from the resourcepoor Loyalty Islands; Bergman doubted whether those from the mainland would be attracted to mining, as they had

«[...] a stronger economic interest in adherence to their still self-supporting tribal organisation. "

The Société le Nickel (SLN), the largest and dominant mining concern in New Caledonia, was also employing some Melanesians (Anderson, 1951a).

Shortly afterwards, in May 1951, there was a substantial change to the electoral system. Anderson advised that a new law had extended the franchise to all adult male Melanesians able to read French and to all adult female Melanesians who were mothers of two or more living children, or mothers of a serviceman killed on active service (Anderson, 1951b). According to Angleviel and Brou, the Governor told his officials to assess the French language test leniently, so that it became little more than a formality, thus boosting the number of new voters (Angleviel, 2006: 27-8; Brou, 1981: 16-17). Although the Melanesians would not attain full suffrage until 1957, the expansion of the Melanesian vote in 1951 had a significant impact.

Anderson provided a lengthy assessment of the implications of this reform. In doing so he set out carefully the terms he was using (Anderson, 1951b). The Melanesians had rarely featured in earlier reporting from him or his predecessors, and it was presumably for that reason that he thought he should clarify his use of terms. $\mathrm{He}$ advised that:

"The term native is used in this context in direct translation of "indigène" the term in official use in New Caledonia - notwithstanding that the majority of the French European community in the Territory is likewise native-born. The term "Melanesian" is not universally applicable, for Polynesians and mixed strains are found in Loyalty Islands and even in certain parts of the east coast on the mainland. The term "Canaque" (Kanaka) on the other hand is a vulgarism, sometimes offensive to native susceptibilities. "

\section{Anderson reported that there had been}

«[...] some disquiet in the European community " when it was realised that in New Caledonia the vote had been extended to nearly 9,000 people in a Melanesian community of 32,500. European voters numbered less than 11,000 in a European community of 21,000 . There had been wishful thinking among some Caledonians

« [...] that few natives would go to the polls or record formal votes.»

It was also suggested that granting the vote to some Melanesian women,

« [...] who occupy an inferior status in the tribal system, would cheapen the vote in native eyes. "

\section{Resentment had also been}

" [...] expressed at the suddenness with which the National Assembly in Paris, without prior consultation of local European interests, had passed legislation of such crucial importance to the Territory's [... future. For not only ha[d] the law assimilated for electoral purposes two racial groups with few common interests or points of contact. Its logical extension - native representation in a common General Council - would involve decisions on matters of general and even of mainly European interest, in which the numerically stronger native community would eventually have a preponderant voice. Even disregarding these implications, the present cultural level of the native community is such as to raise the gravest doubts as to its political capacity. "

Anderson noted that more than 90 per cent of the Melanesians lived on reserves within a tribal structure where

«[...] the chief still retains considerable influence and indeed acts as magistrate in civil affairs. "

Their essentially subsistence agriculture gave them

« [...] a standard of living by no means uncomfortable, though well below European levels.»

In his view they were

" [...] docile and passive in temperament, suggestible and easily swayed. Their development towards a sense of civil identity and civic responsibility has not been assisted by the practical centralisation of authority in the chief $[\ldots]$ "

The Melanesians had benefited from education, but the highest level generally attained was equivalent to fourth grade in an Australian school.

«Official policy ha[d] deliberately maintained educational development at a uniform rate, so that there is no native "intelligentsia" as such and few individuals capable of developing into leaders of opinion. "

Anderson suggests here that officials had averted the emergence of a modern Melanesian 
elite as matter of conscious policy, whereas in fact this circumstance may have resulted more from indifference and neglect. He also gives the impression that the French state had taken on responsibility for Melanesian education, whereas this task had mainly, though not exclusively, been taken on by the Protestant and Catholic missions. (On Melanesian education in the preceding decades, see Pineau-Salaün, 2000.) In more general terms, however, Anderson noted the enduring importance of the Protestant and Catholic missions. He reported that communism had made some progress among the 'detribalised proletariat' of Noumea, and also with two or three chiefs. He observed that

"The handful of French Communists or fellow travellers in Noumea nevertheless represent[ed] the only political group within the European community which has shown any interest in native affairs. "

\section{He said that the Melanesians displayed}

« [...] no understanding of Communist dogma, but Communist slogans make a ready appeal to the few dissatisfied individuals with a sense of communal identity and an unsatisfied desire for 'equality of rights'."

In summary, the Melanesians comprised:

"[...] a politically unconscious mass, with a low level of education and few educated leaders of its own, though most susceptible to mission influence and guidance; and of a very small but active minority with Communist sympathies. »

In the same report, Anderson (1951b) described the four contestants in the election. Roger Gervolino, the 'lacklustre' incumbent,

« [...] had proved acceptable to the established commercial interests which dominate the General Council. [...] [he] had evinced no interest in the native question[...] . and indeed seemed to make no serious bid for the native vote. »

François Paladini described himself as 'Progressive' and was backed by

«[...] the fellow-travelling news sheet Le Calédonien.»

Paladini had built a following as the only candidate

«[...] openly opposed to the dominant commercial interests. »

His campaign offered social services to lowerincome Caledonians and pitched for the Melanesian vote

« [...] by undertaking to press for adoption of a statut indigène establishing their constitutional position, civil rights and effective political representation. »
Two leading chiefs had responded by calling on the Melanesians to vote for Paladini. Another candidate was Maurice Lenormand, a metropolitan pharmacist married to a Loyalty Islander. Anderson said it was '[...] taken for granted in Noumea' that Lenormand was 'sponsored by the missions'. Lenormand had taken a keen interest in Melanesian affairs since his arrival in New Caledonia, and ran 'an able campaign'. He did not challenge Gervolino on any of

" $[\ldots]$ the issues of European concern $[\ldots]$ and indeed outbid him in his defence of the Pacific Franc. His statements on native policy were moderate and measured in tone [...]. [He declared that] without offending any legitimate interest, it will be necessary to promote the conditions and means of progressive evolution within the traditional tribal way of life [...] "

Finally there was Paul Métadier, a former resident and the candidate of de Gaulle's Rassemblement our la France (RPF). He ran a modest campaign, focused on his Gaullist credentials, and made

\section{« $[\ldots]$ no statement on the native question.»}

The election was held on 1 July 1951 . The overall turnout was 70 per cent, with Melanesian participation 'not much inferior' to that of the Europeans. Lenormand won with 5,034 votes, followed by Gervolino (4,207), Metadier $(2,249)$, and Paladini (2,152). Anderson reported that Gervolino and then Metadier had attracted most votes in essentially Caledonian Noumea and its suburbs, with Paladini and Lenormand a long way back. On the West coast (where there was a significant Caledonian presence), Lenormand won a simple majority. In the Melanesian-majority areas of the East coast, the Isle of Pines and the Loyalty Islands, Lenormand won an overall majority, followed by Paladini, and then Gervolino, with Metadier running last. Anderson noted that

" $[\ldots]$ natives in areas under direct mission influence polled solidly for Lenormand. The most striking instance was on Bélep, a strong Catholic mission, where 147 of the 150 recorded votes were cast in his favour. »

Meanwhile Paladini had polled well (595 votes) in Maré where, Anderson noted, high chief Naisseline had 'Communist sympathies.' Paladini had also done well in Lifou,

«[...] [...] where Communist propaganda made considerable headway shortly after the war and is still being combatted by a Protestant Mission, at Houailou [...] and at Bourail [...] the district of a second pro-Communist chief."

Lenormand's victory had been a surprise. Anderson said Lenormand had benefited from the 
splitting of the conservative European vote between Gervolino and Metadier. Anderson recorded a

«[...] widespread tendency in the European community to regard Lenormand as representing native as opposed to European interests, a tendency associated with strong racial prejudice - however unexpected among Frenchmen, against his wife.»

One would note that Lenormand had attracted not only Melanesian votes but also those of a significant number of Caledonians, comprising reformists, workers and rural traders who had developed close links with the Melanesians (see Trépied, 2010: 263-264). The Caledonian community expressed, Anderson said,

« [...] alarm at the size and solidity of the native vote, which in a sense obtained the election of its "own" candidate. The active role of the Missions has also been much criticised and has given rise to a certain amount of anti-clerical feeling. Finally some anti-metropolitan sentiment has been generated by the suddenness of the French National Assembly's decision in adopting Law No. 51/586 [which had extended the franchise]. Most important, however, the European community has been stirred into giving some thought to the native question.» (Anderson, 1951b)

An open letter to the General Council, signed by several leading citizens, appeared in La France Australe on 25 July (clipping held with Anderson, 1951b). The correspondents underlined

«[...] the absence of common interests between the two racial groups $[\ldots]$ »

They said they wrote on behalf of 'the Caledonian Population', which had built New Caledonia, and had served loyally in both world wars. There were distinctions between the Caledonian and Melanesian communities, but relations were harmonious. They called for two electoral colleges, one for European and one for Melanesian voters.

Anderson reported that French officials and the Missions were less perturbed than the Caledonians by the election outcome. They were

«[...] confident that with wise guidance and by a gradual process of moderate evolution the native community can ultimately be brought to a level of political capacity at which its voting rights could be freely exercised without a clash of interests with the European community and without serious intercommunal feeling. " (1951b)

Following the election Pastor Lacheret, who headed the Protestant mission, confirmed mission support. He told Anderson that it had been at his direct initiative that Lenormand was invited to stand. The Protestant mission had been apprehensive about

« [...] the dangers implicit in leaving the newly enfranchised native community without direction, and it was further impressed with the importance of electing a Deputy with an understanding of the native question.»

\section{It had regarded Lenormand}

«[...] as the only moderate candidate well-informed and interested in native affairs, capable of framing a moderate native policy, and likely to have a wide electoral appeal among the native community.»

The Catholic Church took a similar stance. Anderson reported that

«[...] a private conversation with Mr Stéphane de Saint-Quentin, who may be said to represent the Catholic interest in the General Council, left me in no doubt that the Pastor's view was fully shared by the episcopate.»

In November 1951 Anderson (1951c) reported further on the implications of the new political circumstances. He noted that Senator Lafleur had indicated to his colleagues during his recent visit to Noumea that he still hoped the French Government

«[...] could be induced to table legislation restricting effective native participation in the Council.»

In an earlier discussion Rouleau, the Head of the Native Affairs Department, had told Anderson that it might be too late for a double electoral college to be arranged, however desirable, but did not expect

«[...] heavy native representation in the General Council for many years to come (Anderson, 1951b).»

In November Rouleau told Anderson that he saw no prospect for special dual arrangements, but advised that the French administration in New Caledonia

«[...] had recommended to the French Government an increase in the number of seats in the General Council to take account of the increased size of the electorate, but so distributed as to safeguard European preponderance in the Council for a considerable time to come.» (Anderson, 1951c)

Anderson reported that he thought that Henri Bonneaud, the President of the General Council, a strong advocate for Caledonian rights and interests, and for the double electoral college, would nonetheless be satisfied if, as Rouleau expected, only four or five Melanesian councillors were returned at the next election (Anderson, 1951c).

While determined to defend their position, Bonneaud and the other General Council members were aware that circumstances were evolving. Anderson reported that at the November 1951 session of the General Council, 
" $[\ldots]$ the $[\ldots]$ Council has shown an unaccustomed interest in native welfare and the Native Affairs Department. " (Anderson, 1951d)

Previously the Council had paid little attention to Melanesian issues. Drawing on a press report, Anderson advised that Bonneaud had stressed that the Council had not been informed of an administrative decision to reduce the amount in the budget for public works in the Melanesian communities. Bonneaud had also criticized a statement by the Head of Native Affairs that a lack of funds had prevented the completion of the registration of the Melanesian population, claiming that the present Council had '[... never refused credits for the examination of such important matters.' One Councillor asked for a scientific investigation into the taro disease

« $[\ldots]$ in order to examine the steps to be taken to protect this important native crop."

The General Council also called for the reorganisation of the Native Affairs Department, in view of

« [...] the social evolution of the natives over the last fifty years and more and also the new rights conferred on them. »

Anderson noted that the Native Affairs Department comprised the Head and a secretary-typist, and the gendarmes who represented it in the interior. It appears that there was scope to increase its staffing. In DecemberAnderson reported on the proposed legislation for new election arrangements for the General Council (Anderson, 1951e). He understood Bonneaud had asked Senator Lafleur to work for the elimination of the fifth seat provisionally allocated to the Loyalty Islands, because the electors in this division constituted less than half of the total Melanesian electorate. In a recent debate in the National Assembly, Lenormand had attacked the Government's draft Bill, which he saw as an attempt to introduce a double college system, which Anderson said was what it amounted to. Lenormand had presented a counter-proposal with a single college. 'In the eyes of the present General Council,' Anderson said, Lenormand's proposal would entail

« [...] an ultimate, if not an immediate danger of native predominance in the Council.»

In response to this concern, Lenormand had put emphasis on proposed 'union lists' which would include both European and Melanesian candidates. Anderson advised that the present General Council regarded the approach of Lenormand as

" [...] theoretical, unrelated to considerations of practical politics, and extremely dangerous for the future. »

\section{In Anderson's view,}

"It would be unfortunate, however, if their present differences should lead to an open breach, for the Council as at present composed almost certainly commands the support of most Europeans, while Lenormand could probably carry the native community with him. Such a situation could only benefit the little group of Communists and fellow-travellers associated with Le Calédonien, which is so far the only newspaper to publish Lenormand's speech [to the National Assembly] or indeed to give any account of it. » (Anderson, 1951e)

Anderson's reporting attracted favourable attention in Canberra. One official commented that Anderson's memoranda

«[...] supplement[ed] material which has important political significance - to wit - [the] native vote everywhere.» (Kuskie et al., 1951)

Officials agreed to thank Anderson for his memoranda, and to ask him for more reports in the form of despatches, thus ensuring wider circulation. They also decided on the preparation of a paper drawing on Anderson's reports for Current Notes on International Affairs, an official publication directed to the policy community, the press and the educated public. This article appeared a few months later (External Affairs, 1952).

In 1951 and 1952 complicated politicking took place on the issue of the franchise, both in metropolitan France and in New Caledonia. In April 1952 Anderson reported that both a French government bill and bill put forward by Duveau, the deputy for Madagascar, appeared

«[...] to make generous provision for the political aspirations of the Melanesian and MelanesianPolynesian inhabitants of New Caledonia. (Indeed, there is little evidence of any such aspirations among the native community prior to [the] passage of the 1951 electoral law.) The stage of development attained by the average New Caledonian native may be somewhat higher than that of the mission-trained Papuan, but it is still far below that of the Maori. It is true, as Mr. Lenormand emphasized in the Assembly, that since 1917 the European and native communities have lived side by side without evident friction: this seems to be due less to any genuine intercommunal understanding than to the width of the social division between them, resulting partly from the superior economic power of the European but also from the native's own tenacious adhesion to the tribal way of life. Mr Lenormand also spoke in the Assembly of progress in the field of native education. This certainly represents a dynamic factor in the situation which should not be discounted, but the cultural and economic level of the average native voter of tomorrow is still such, judged by liberal democratic standards, as to raise grave doubts of his political capacity. However this may be, far-reaching political rights have already been given to some fifty per cent of the adult native community and it is likely that the 
clock will be put still further forward. In these circumstances, and whatever the form and colour of the General Council which emerges from proceedings in Paris, the rift that has now appeared between Mr. Lenormand and his parliamentary colleagues is a most disquieting development.» (Anderson, 1952)

\section{Anderson feared Lenormand's robust approach was}

« [...] not calculated to promote that harmonious association of the two communities to which Mr. Lenormand has dedicated his parliamentary career. The sincerity of his intentions has not been questioned by those who know him well, but the present direction of his efforts as spokesman for the native interest is likely to be of most benefit to the handful of Noumea Communists and fellow-travellers who already command a small native following.»

Eventually a compromise was reached comprising a single electoral college but with representation skewed in favour of the European population. (Angleviel, 2006: 29-30, 52, 58; Kurtovitch, 1997b: 44).

Elections were held on 8 February 1953 for the General Council. Lenormand's Union Calédonienne (UC) list gained the great majority of Melanesian votes, and a minority of Caledonian votes. It won 14 of the 25 seats, achieving, with the support of another elected representative, a majority of 15. Brou (1981: 25) described the result as a 'crushing victory' for UC. For the first time, the Council had Melanesian members: those elected included nine Melanesians, all of whom had stood on the Uc list. The new Council met for the first time on 26 February 1953. The pressing issue of the day was a strike by New Caledonia's public servants. The strikers wanted the Council to agree to the implementation in New Caledonia of a French government decision to raise the salaries of public servants in France and its territories. Anderson (1953) reported that the Council had some sympathy for the demands of the strikers, but was concerned about the pressure on the territorial budget if these demands were met. But the Council's concentration on this issue had 'one important consequence' in that both the UC majority and the conservative Caledonian opposition

" [...] were of one mind in protesting against the failure of "the Metropolis" to consult the local assembly on a measure which was bound to have far-reaching effects on the local budget. The issue thus drew both parties together and eventually brought them into effective collaboration, to a point at which the regular Council committees were for practical purposes by-passed by informal meetings of representatives of all groups. (The nine native Councillors, incidentally, took little part in these discussions, contenting themselves with observing and voting with their group as the occasion required; and indeed only three members of the majority[...] Lenormand, Bergès and
Caron[...] seem to have been active throughout the proceedings.) A similar pattern appears to have been followed in subsequent Council meetings, and relations between majority and opposition seem much more cordial than could have been anticipated at the opening of the first session. In conversation on $12^{\text {th }}$ March, the Deputy Lenormand told me that he was now confident that a cordial and efficient working relationship between the two groups would eventually be established on a solid basis. "

Lenormand's hopes for cooperation would be disappointed, but for the moment the anxiety of those who had been concerned by the implications of greater Melanesian involvement in elections and the political system had been allayed. (On the first generation of Melanesian elected representatives, see Soriano, 2014.)

In the early 1950s, through their involvement as voters in substantial numbers for the first time, the Melanesians of New Caledonia took a decisive step on the long road to emancipation. In the years ahead, the French administration, the missions and conservative Caledonian leaders would continue their efforts to manage, in support of their own respective specific interests, increased Melanesian participation in the electoral system (Ward, 1988: 99-100). For their part, for several years the Melanesians were prepared to seek to work with the Caledonians and remained loyal to France.

\section{Conclusions}

Any conclusions we might draw from the various Australian perspectives presented here on New Caledonia's Melanesians in the decade or so from 1941 can only be tentative, because of the episodic nature of the comments, the small number of those who commented, their varied standpoints, their use of secondhand information, and their lack of sustained direct contact with the Melanesians. But it is noteworthy that the Australian military officers, who were presumably practical, down-to-earth men, and who had some direct contact with Melanesians, rose in part above the constraints of preconceptions and prejudices and came away with a favourable impression. Direct contact can make a difference. In the late 1940s the views of Barnett, Smith and Kelly appear to have been shaped by the views of their Caledonian informants. Smith did recognise, however, that the elevation of two Melanesians to the priesthood had shown a Melanesian capacity for education. In the early 1950s Lawrey and Anderson took a more liberal stance. In Anderson's view the Melanesians of New Caledonia had reached a development stage well below that of the Maori of New Zealand, but higher than that of the 
'mission-trained Papuan'. He was relieved when the initial participation of Melanesians in the General Council went smoothly, and did not disrupt the stability of New Caledonia.

Some of the reports discussed in this article also provide further evidence for this period of the intolerance and inflexibility of many Caledonians. The persistence of attitudes of this kind no doubt contributed, in some measure, to the emergence in the 1970s of strongly militant Melanesian nationalism.

\section{Aknowledgements}

The author is grateful for the insightful comments on an earlier draft of this article by JSO's editor and readers.

\section{BIBLIOGRAPHY ${ }^{3}$}

Aldrich Robert, 1993. France and the South Pacific since 1940, London and Basingstoke, MacMillan.

Anderson H.D. (David), 1951a (5/04). Memorandum, 5 April, A1838, 326/5/1.

—, 1951b (4/08). Despatch, A1838, 323/1, part 1.

—, 1951c (21/11). Despatch, CP553/1, Bundle 31/272/A/1/B.

—, 1951d (23/11). Memorandum, A1838, 323/4/1.

—, 1951e (12/12). Memorandum, A1838, 323/4/1.

—, 1952 (9/04). Ministerial Despatch, A1838, 323/1, part 2.

—, 1953 (9/03). Ministerial Despatch, A1838, 323/1, Part 3.

Angleviel Frédéric, 2006. Brève histoire politique de la Nouvelle-Calédonie contemporaine (1945-2005), Nouméa, Éditions du GRHOC.

Australian Mission, 1941 (Feb-March). Report of the Australian Mission to New Caledonia, A2670, 282/1941.

Ballard B.C. (Bertram), 1943 (17/11). Memorandum to DEA, A6445, 392/1947.

-, 1944. Memorandum to DEA, 4 January 1944, A6445, 392/1947.

Barnett H. (Hal), 1946. Despatch, 9 May, A1838, 323/1, part 1.

—, 1947 (17/01), Despatch 2, A1838, 323/1, part 1.
Brou Bernard, 1981. 30 ans d'histoire politique et sociale de la Nouvelle-Calédonie, de 1945 à 1977, Nouméa, Société d'études historiques.

Burchett Wilfred, 1941. Pacific Treasure Island. New Caledonia, Melbourne, F. W. Cheshire Pty. Ltd.

Commonwealth of Australia, 1948. Foreign Service Conditions-Noumea, A1838, 326/1, part 1.

Connell John, 1987. New Caledonia or Kanaky? The political history of a French colony, Canberra, National Centre for Development Studies.

Cumpston J.S., 1954 (23/04). Despatch, A1836, 326/1, part 2. (See also 'Australian Consulate Premises', 28 May 1953, on the same file.)

Deschamps Hubert and Jean Guiart, 1957. Tahiti (La Polynésie française). Nouvelle-Calédonie. Nouvelles-Hébrides, Paris, L’Union française.

External Affairs (Department of), 1943 (16/07). DEA to Noumea, A6445, 392/1947.

—, 1943 (16/12.). DEA To Noumea, A6445, 392/1947.

—, 1949. Duties of Australian Consul, Noumea, A1838, 326/1, part 1 .

—, 1952. Constitutional Developments in the French Pacific Territories, Current Notes on International Affairs 23, 7, pp. 331-38.

External Affairs (Minister), 1942 (12 January). Cable to Secretary, Dept of Defence Coordination, A461, B350/1/9, Part 2.

External Affairs (Pacific Division), 1948 (8/07). Report on the Activities of the Australian Consul, Noumea, A1838, 326/1, part 1.

Garland Ron, 1997. Nothing is Forever. The History of 2/3 Commandos, Sydney, published by author.

Henningham Stephen, 2014. Australia's Economic Ambitions in French New Caledonia, 1945-1955, The Journal of Pacific History 49, 4, pp. 421-439.

—, 2016 (forthcoming). Anxious neighbour: Australian opposition to Japanese labour in New Caledonia, 1945 to 1960, The Australian Journal of Politics and History, Brisbane.

Kelly K.T, 1948 (28/09). Report on the Economic and Financial State of the Government and Colony of New Caledonia, annexed to Despatch, A1838, 324/1/2.

Kuskie, B. et al., 1951 (14/09). comprising notes by Kuskie, Warren, Harry and Powell, held on file with Anderson to DEA, memorandum, 323/1, Part 2.

3. All files cited are from the National Archives of Australia (NAA). 
Kurtovitch Ismet, 1992. De la réglementation du travail obligatoire pendant la Seconde Guerre mondiale, Etudes mélanésiennes 29, pp. 37-55.

—, 1996. Du régime fiscal pendant la seconde guerre mondiale, Etudes mélanésiennes 30, pp. 5-17.

—, 1997a. Sortir de l'indigénat : cinquantième anniversaire de l'abolition de l'indigénat en Nouvelle-Calédonie, avec une introduction de Jean Guiart, Journal de la Société des Océanistes 105, pp. 117-139.

—, 1997b. New Caledonia: The Consequences of the Second World War, in Aldrich, Robert and Isabelle Merle (eds), France Abroad. Indochina, New Caledonia, Wallis and Futuna, Mayotte, Sidney, University of Sydney, Department of Economic History, pp. 34-45.

—, 1998. La vie politique en Nouvelle-Calédonie : 1940-1953, Villeneuve-d'Ascq, Presses universitaires du Septentrion.

—, 2000. A Communist Party in New Caledonia (1941-1948), The Journal of Pacific History 35, 2, pp. 163-179.

LaWrey L.J (John), 1950 (11/07). Memorandum, A1838, 323/4/1.

LaWrey John, 1982. The Cross of Lorraine in the South Pacific, Canberra, PHA.

Leblic Isabelle, 1993. Les Kanak face au développement. La voie étroite, Grenoble, PUG.

-, 2007. Kanak Identity. New Citizenship Building and Reconciliation, Journal de la Société des Océanistes 125, pp. 271-282 (http://jso.revues.org/1004).

Mohamed-Gaillard Sarah, 2010. L'Archipel de la puissance? La Politique de la France dans le
Pacifique Sud de 1946 à 1990, Bruxelle, P.I.E.Peter Lang S.A, Enjeux internationaux 9.

Pineau-Salaün Marie, 2000. Histoire et mémoire d'un institution colonial. Le scolarisation des Kanak au temps de l'indigénat, in A. Bensa et I. Leblic, En pays kanak, Paris, éd. de la MSH, pp. 253-269.

Priday H.E.L. 1944. Cannibal Island: The Turbulent Story of New Caledonia's Cannibal Coasts, Wellington, A.H and A.W. Reed.

Shineberg Dorothy, 1986. Wilfred Burchett's New Caledonia, in Ben Kiernan (ed.), Burchett. Reporting the Other Side of the World, 19391983, London, Quartet Books, pp. 137-147.

Sмiтн J.T., 1948. Report of Australian Economic Mission to New Caledonia (by Member Representing Department of Commerce and Agriculture), A431, 48/15594.

Soriano Éric, 2013. La fin des Indigènes en Nouvelle-Calédonie. Le colonial à l'épreuve du politique 1946-1976, Paris, Karthala, Karappa.

Spender Percy, 1950 (March). Statement on Foreign Policy to House of Representatives, copy held on A1838, 568/8, part 4.

Thompson Roger C., 1998. Australia and the Pacific Islands in the 20th Century, Melbourne, Australian Scholarly Publishing.

Trépied, Benoît, 2010. Two Colours, One People? The Paradoxes of the Multiracial Union Calédonienne in the Commune of Koné (New Caledonia, 1951-1977), The Journal of Pacific History 45, 2, pp. 247-264.

WARD Alan, 1988. Labour Policy and Immigration, in Michael Spencer, Alan Ward, and John Connell (eds), New Caledonia. Essays in Nationalism and Dependency, St Lucia, University of Queensland Press, pp. 81-105. 